\section{The Carbohydrate Yield of Sweetpotato (Ipomoea batatas) Grown from Slips and Root Pieces in North Carolina}

\author{
Nicholas A. George \\ Department of Horticultural Science, North Carolina State University, 214 \\ Kilgore Hall, Campus Box 7609, Raleigh, NC 27695; and Department of \\ Plant Sciences, the University of California, Davis, One Shields Avenue \\ Davis, CA 95616 \\ Kenneth V. Pecota and G. Craig Yencho ${ }^{1}$ \\ Department of Horticultural Science, North Carolina State University, 214 \\ Kilgore Hall, Campus Box 7609, Raleigh, NC 27695
}

Additional index words. sweetpotato, Ipomoea batatas, carbohydrate yield, multienvironment trial

\begin{abstract}
Sweetpotato (Ipomoea batatas) is one of the world's most important and widely grown starch crops. It is usually produced for direct human consumption but can be readily converted to simple sugars that then have industrial end uses. The objective of this study was to compare the carbohydrate yield of the conventional sweetpotato cultivar, Beauregard, with new clones selected specifically for higher carbohydrate production. Ten sweetpotato clones were grown from both slips and root pieces at five locations, over 2 years, in North Carolina. A sweetpotato clone selected for high carbohydrate production, and planted as slips, yielded on average $4150 \mathrm{~kg} \cdot \mathrm{ha}^{-1}$ of carbohydrates, $10 \%$ to $15 \%$ higher than Beauregard. The chemical composition of roots was unaffected by planting method, but slips usually outyielded the same clone grown from root pieces. Carbohydrate yield was significantly impacted by genotype $\times$ environment effects in both slips and root pieces. We conclude that further work will be needed to develop sweetpotato clones with both high carbohydrate content and high yield potential, and that are also adapted to planting from root pieces. Any breeding and development work will need to take into account genotype $\times$ environment effects.
\end{abstract}

Sweetpotato (I. batatas) is one of the world's most important and widely grown starch crops (FAOSTAT, 2014). Sweetpotato is grown primarily for direct human consumption, or as a processed food product, but sweetpotato biomass can be readily converted to simple sugars, which then have industrial end uses such as for the production of fuels (e.g., ethanol or butanol) or bioplastics (United States Sweet Potato Council, 2011; Ziska et al., 2009).

Sweetpotato has traits that make it attractive as an alternative carbohydrate crop to corn in the eastern United States - ease of propagation, tolerance of different soil types, fast growth rates, and wide harvest windows. The eastern United States also has a pre-existing

\footnotetext{
Received for publication 12 May 2015. Accepted for publication 2 Sept. 2015.

The project was funded by a grant from the Biofuels Center of North Carolina.

We sincerely thank the staff of the NCSU Sweetpotato and Potato Breeding and Genetics Program, the North Carolina Department of Agriculture and Consumer Services Horticultural Crops, Upper Piedmont, Oxford Tobacco and Tidewater Research Stations, and the NC State University Williamsdale Farm and Agricultural Extension and Research Center.

${ }^{1}$ Corresponding author. E-mail: Craig_Yencho@ ncsu.edu.
}

sweetpotato industry with readily available production equipment, university-based research support, and experienced extension agents, which would facilitate the adoption of sweet-

In the eastern United States, it has been shown that the carbohydrate yield of sweetpotato can exceed that of corn, $11,000 \mathrm{~kg} \cdot \mathrm{ha}^{-1}$ vs. $5,900 \mathrm{~kg} \cdot \mathrm{ha}^{-1}$, respectively (Ziska et al., 2009). Historically, sweetpotato breeding programs have focused on developing cultivars for human consumption, but desirable quality traits for food markets differ from those for industrial end uses. In the United States, the dry matter content of sweetpotato rootswhich is generally accepted to be closely related to carbohydrate content-is $\approx 20 \%$ for most commercial clones. It should be possible to select for new clones with similar yields to conventional clones but dry matter contents of around $30 \%$, thereby increasing total carbohydrate yield. In addition, by removing the two constraints to breeding sweetpotato for food markets - appearance and size distribution-faster progress can be made toward high carbohydrate production.

The production of sweetpotato is relatively expensive and if it is to be a viable industrial carbohydrate crop it will be necessary to lower production costs. High costs can be attributed in part to the need for manual labor at planting. Sweetpotato is generally propagated using potato as an industrial crop. unrooted stem cuttings, called "slips," and in the U.S. manual labor associated with planting slips is estimated to be between $15 \%$ and $20 \%$ of total production costs (Estes et al., 2002; Hinson and Boudreaux, 2007; Martin et al., 2000; MSU, 2007). An alternative propagation method is to use root pieces, similar to the system used for potatoes (Solanum tuberosum), which uses cut tubers as "seed" and can be mechanized and therefore reduces labor demands. The yield of existing commercial sweetpotato cultivars planted as root pieces tends to be lower than for slips (George et al., 2011).

It has been found that sweetpotato grown from both slips and root pieces can display significant genotype by environment interaction $(\mathrm{G} \times \mathrm{E})$, and yield instability (Collins et al., 1987; George et al., 2014; Grüneberg et al., 2005; Kanua and Floyd, 1988; Manrique and Hermann, 2002; Ngeve, 1993), making it difficult to predict the performance of clones across sites and years, and complicating cultivar development.

In our study, the sweetpotato cultivar Beauregard was grown in a multienvironment trial with other sweetpotato clones specifically selected for high dry matter production. All clones were grown from both slips and root pieces. The objectives of the research were: 1) to estimate the carbohydrate yield of all the sweetpotato clones under commercial-like production conditions, 2) to compare the carbohydrate yield of Beauregard with new clones selected for higher carbohydrate content, 3 ) to directly compare carbohydrate production from slip and root piece planting methods, and 4) to test the significance of $\mathrm{G} \times \mathrm{E}$ effects on the carbohydrate yield of clones grown from both slips and root pieces.

\section{Material and Methods}

Varieties, trial sites, soils, and cultural practices. The sweetpotato cultivar Beauregard (Rolston et al., 1987) is commonly grown for human consumption in the United States. Ziska et al. (2009) used Beauregard in their study comparing the carbohydrate yield of corn, cassava, and sweetpotato in the eastern United States. In this study, Beauregard was grown along with the clones NCFTA94, NCDM02105, NCDM02-180, NCDM03-104, NCDM04197, NCP05-063, NCP06-010, and NCP06-014, which had been selected for high dry matter production. The clone NCDM02-105 had also been selected for adaptation to root piece planting. The low-dry matter clone NC07-364, also selected for adaptation to root piece planting, was included so its performance from slips and root pieces could be compared with the other clones. The "NC" clones were developed by the North Carolina State University Sweetpotato Breeding and Genetics Program (NCSU SBGP).

Five research sites within North Carolina were used for the multienvironment trials (Table 1). The sites had differing soil types and represented both conventional and unconventional sweetpotato production areas. The Clinton site was chosen as being representative 
of soils commonly used for commercial sweetpotato production in North Carolina. It is one of two sites used for breeding and selection activities by the NCSU SBGP and is therefore one of the environments where the NCSU SBGP lines were originally selected. The other four sites represented soil types not commonly used for sweetpotato production but to which commercial production could be expanded. All the sites had similar daylength but varying climatic conditions throughout the study.

Soil analyses were conducted by the Agronomic Division of the North Carolina Department of Agriculture and Consumer Services. Additional soil information was obtained from the Web Soil Survey (NRCS, 2013).

Climatic details for each site were obtained from the State Climate Office of North Carolina and the National Oceanic and Atmospheric Administration National Climatic Data Center. Daylight hours were obtained from the U. S. Naval Observatory (USNO, 2012) (Table 2). Growing degree days were estimated using a basal temperature of $15.6{ }^{\circ} \mathrm{C}$ and maximum temperature of $32^{\circ} \mathrm{C}$ (Villordon et al., 2009). The temperature and rainfall during the study period were within a standard deviation for each location.

Propagation material. The Clinton site was used as the source of root piece material for all the trial sites to avoid possible location effects on the subsequent performance of crops. Storage roots weighing between 100 and $200 \mathrm{~g}$ were used for producing root pieces. Each root was cut in half transversely to produce a root piece weighing between 50 and $100 \mathrm{~g}$. Root pieces were treated with Dicloran $\left(1 \mathrm{~g} \cdot \mathrm{L}^{-1}\right)$ for the control of fungal rots then presprouted at 30 to $32{ }^{\circ} \mathrm{C}$ and $80 \%$ humidity for 1 week in a climate-controlled "presprouting" room. Slips were cut from roots bedded at the Clinton site following normal commercial production practices.

Site preparation, planting, management, and harvest. An effort was made to ensure agronomic practices were as consistent as possible across sites. Command 3ME (clomazone; FMC Corporation, Philadelphia, PA) at 3 L.ha ${ }^{-1}+$ Eptam (EPTC; Gowan Company, Yuma, AZ) at $4 \mathrm{~L} \cdot \mathrm{ha}^{-1}$ were preplant incorporated for weed control before planting in formed beds. In the 2nd year, Valor (flumioxazin; Valent, Walnut Creek, CA) at $200 \mathrm{~g} \cdot \mathrm{ha}^{-1}$ was applied as a pre-emergent herbicide following bedding. Poast (sethoxydim; BASF Corp., Research Triangle Park, NC) was applied at the species label rate when grass control was needed. Interrows were cultivated for weed control. Fertilizer application rates are given in Table 2. Fertilizer was applied to ensure no nutrients were limiting, based on soil analyses, field history, and what was practical given existing fertilizer blends available at individual research stations. No irrigation was applied to the sites on the assumption that the use of irrigation is not economically viable if sweetpotatoes are being grown only for industrial end uses.
Root pieces were planted either by hand, or using a two-row seed-piece planter (Model RP-20M 2-Row Assisted Feed Planter; US Small Farm Equipment Company, Torrington, WY), at a depth of $\approx 5 \mathrm{~cm}$. Slips were planted once sprouts from root pieces emerged from the soil surface $(\approx 3$ to 4 weeks later). Both root pieces and slips were planted on an intrarow spacing of $30 \mathrm{~cm}$ with either 20 or 30 pieces per plot. Plots consisted of a single row, with 1.1-m spacing between bedded rows and $2.5-\mathrm{m}$ unplanted alleys between plots. The sites were arranged in randomized complete block designs with four replicates.

Stand counts were conducted between 30 and $40 \mathrm{~d}$ following planting. The number of days between planting and harvest varied by year and location, and ranged from $\approx 120$ to $180 \mathrm{~d}$. In practice, this meant sites were harvested when minimum daily temperatures began dropping below $10^{\circ} \mathrm{C}$.

At harvest, foliage was removed using a flail mower and then roots were unearthed using a chain digger. Storage roots from each plot were sorted into enlarged root pieces (mother roots) and daughter roots (George et al., 2011). A sample of three daughter roots were taken from each plot, chipped in a food processor, and freeze-dried for dry matter and compositional analysis. Dry matter data and plot area were used to convert daughter root yield to dry matter yield per hectare.

Compositional analysis. The total dry matter content of the storage roots was determined by

Table 1. Research locations and soil classifications used in 2010 and 2011.

\begin{tabular}{|c|c|c|c|}
\hline Site & Site name & Location & Soil type \\
\hline$\overline{\text { Clinton }}$ & $\begin{array}{l}\text { Horticultural Crops Research Station, NC } \\
\text { Department of Agriculture and Consumer Services }\end{array}$ & Clinton, NC, $35.024 \mathrm{~N} 78.28 \mathrm{~W}$ & $\begin{array}{l}\text { Norfolk, Wagram, and } \\
\text { Orangeburg loamy sands }\end{array}$ \\
\hline Wallace & $\begin{array}{l}\text { Williamsdale Farm and Agricultural Extension and } \\
\text { Research Center, North Carolina State University }\end{array}$ & Wallace, NC, 34.762 N $78.099 \mathrm{~W}$ & $\begin{array}{l}\text { Noboco loamy fine sand and } \\
\text { Goldsboro loamy sand }\end{array}$ \\
\hline Oxford & $\begin{array}{l}\text { Oxford Tobacco Research Station, NC Department } \\
\text { of Agriculture and Consumer Services }\end{array}$ & Oxford, NC, $36.302 \mathrm{~N} 78.613 \mathrm{~W}$ & Helena sandy Loam \\
\hline
\end{tabular}

Table 2. Site management and climatic details for the research sites used in this work.

\begin{tabular}{|c|c|c|c|c|c|c|c|c|c|c|}
\hline \multirow[b]{3}{*}{ Season } & \multicolumn{10}{|c|}{ Research sites } \\
\hline & \multicolumn{2}{|c|}{ Clinton } & \multicolumn{2}{|c|}{ Wallace } & \multicolumn{2}{|c|}{ Reidsville } & \multicolumn{2}{|c|}{ Oxford } & \multicolumn{2}{|c|}{ Plymouth } \\
\hline & 2010 & 2011 & 2010 & 2011 & 2010 & 2011 & 2010 & 2011 & 2010 & 2011 \\
\hline Planted-root pieces & 7 May & 4 May & 28 May & 2 May & 3 May & 9 May & 3 May & 9 May & 4 May & 10 May \\
\hline Harvested & 19 Oct. & 19 Oct. & 9 Nov. & 26 Oct. & 12 Oct. & 17 Oct. & 11 Oct. & 18 Oct. & 20 Sept. & 5 Oct. \\
\hline Days to harvest-root pieces & 165 & 168 & 165 & 177 & 162 & 161 & 161 & 162 & 139 & 148 \\
\hline Days to harvest-slips & 151 & 141 & 144 & 166 & 132 & 132 & 131 & 133 & 125 & 121 \\
\hline Maximum temperature $\left({ }^{\circ} \mathrm{C}\right)$ & 37 & 39 & 36 & 39 & 36 & 37 & 38 & 38 & 38 & 39 \\
\hline Total precipitation (mm) & 801 & 643 & 961 & 656 & 634 & 502 & 458 & 250 & 445 & 883 \\
\hline Maximum daily precipitation $(\mathrm{mm})$ & 102 & 95 & 102 & 133 & 102 & 60 & 84 & 56 & 56 & 312 \\
\hline Growing degree days & 4,045 & 4,018 & 3,916 & 4,208 & 3,823 & 3,703 & 3,911 & 3,881 & 3,567 & 3,728 \\
\hline Humic matter (\%) & 0.54 & 0.3 & 0.86 & NA & 0.22 & 0.32 & 0.36 & 0.36 & 4.44 & 4.56 \\
\hline Cation exchange capacity & 3.1 & 3.0 & 9.2 & 5.0 & 4.9 & 4.6 & 4.2 & 5.4 & 8.6 & 9.6 \\
\hline $\mathrm{pH}$ & 5.7 & 6.2 & 6.7 & 5.4 & 5.7 & 6.5 & 6 & 5.9 & 5.2 & 5.1 \\
\hline $\mathrm{N}$ fertilization $\left(\mathrm{kg} \cdot \mathrm{ha}^{-1}\right)$ & 80 & 110 & 80 & 0 & 90 & 70 & 90 & 30 & 0 & 0 \\
\hline
\end{tabular}



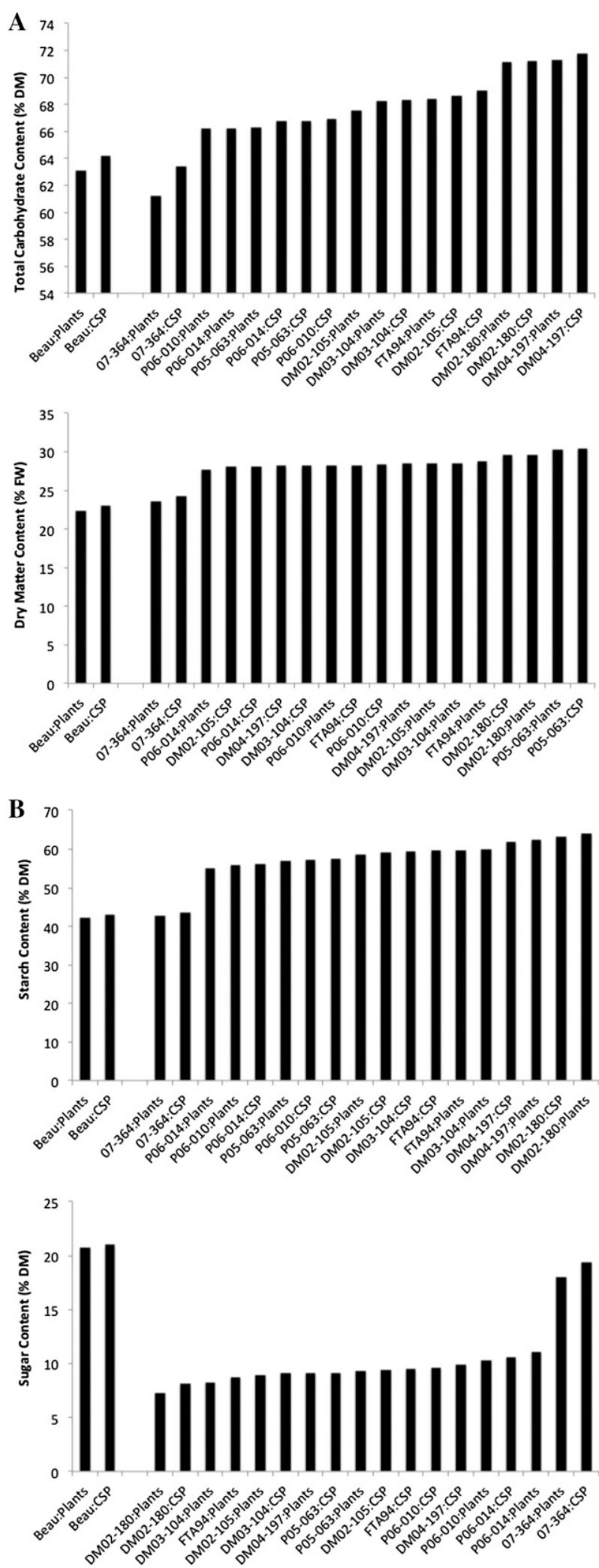

Fig. 1. The root composition of the sweetpotato clones tested in this study (best linear unbiased predictors from linear model). Beau $=$ Beauregard; plants $=$ planted as slips; $\mathrm{CSP}=$ planted as root pieces. Error estimates at not shown for individual grouping factors given these are random terms in the model (Bates, 2010).

measuring the mass of root material following freeze-drying. After freeze-drying, the storage root material was ground to pass through a $1-\mathrm{mm}$ sieve using a cyclone grinder (CYCLOTECH 1093 Sample Mill,
FOSS Tecator; Hoganas, Sweden). Ground material was used for chemical analyses via both "wet chemistry" and near-infrared (IR) methods (see below for wet chemistry methodology).
Near-IR absorbance (NIR) spectra for the dried samples were collected for the region from 1100 to $2500 \mathrm{~nm}$ with a scanning nearIR spectrometer (FOSS XDS Rapid Content Analyzer) and the software ISIscan 2010 (Foss, Eden Prairie, MN). The software WinISI 2010 (Foss) was used to select representative root samples for "wet chemistry" analysis.

Prediction equations used in this study were based on $\approx 7000$ individual scanned sweetpotato samples representing a range of genetic backgrounds, locations and years taken by the NCSU SBGP, including representative material from this study.

The starch and sugar content of the ground root material used for NIR calibration were measured using commercial enzyme-based analytical kits (Megazyme International Ireland, Bray Business Park, Ireland). The starch analytical procedure used thermostable $\alpha$-amylase and amyloglucosidase and was modified for samples containing D-glucose and/or maltodextrins (AOAC Method 996.11 AACC Method 76-13.01 RACI). The D-glucose concentration was determined before and after hydrolysis of sucrose by $\beta$-fructosidase (invertase) and the D-fructose content of the sample was determined after the determination of D-glucose after isomerization by phosphoglucose isomerase (Beutler, 1988; Kunst et al., 1988; Outlaw and Mitchell, 1988).

Statistical analyses. All data manipulation and statistical analyses were conducted using the program R (R Core Team, 2014). Tests for correlations between measured traits were conducted using the add-on package "Performance Analytics Correlation" (Carl and Peterson, 2013). Correlations were based on the Pearson's product moment correlation coefficient. Exploratory analysis of the data set found significant variance heterogeneity between sites and years so it was necessary to use a linear mixed-effects analytical procedure to test the significance of main effects and their interactions (Smith et al., 2005). The model considered clone, site, and year as fixed effects, replicate within site as a random effect, and to account for variance heterogeneity separate residual variance was specified for Year within Site. Normality and variance homogeneity of the linear mixed model were evaluated by visual inspection of plots of residuals. To estimate compositional phenotypes and rankings for individual clones, best linear unbiased predictions were calculated using the $\mathrm{R}$ add-on package "lme4" (Bates et al., 2013) treating clone as a random effect (Pinheiro and Bates, 2000; Smith et al., 2005). Significant $\mathrm{G} \times \mathrm{E}$ effects are often considered important only if associated with crossover events (Truberg and Huhn, 2000) and a measure of varietal stability to environmental change is also useful for determining if varieties are broadly or specific adapted (Smith et al., 2005). The add-on package "Agricolae" was therefore used for nonparametric stability analysis according to Huehn (1990) and Mendiburu (2013). 
A
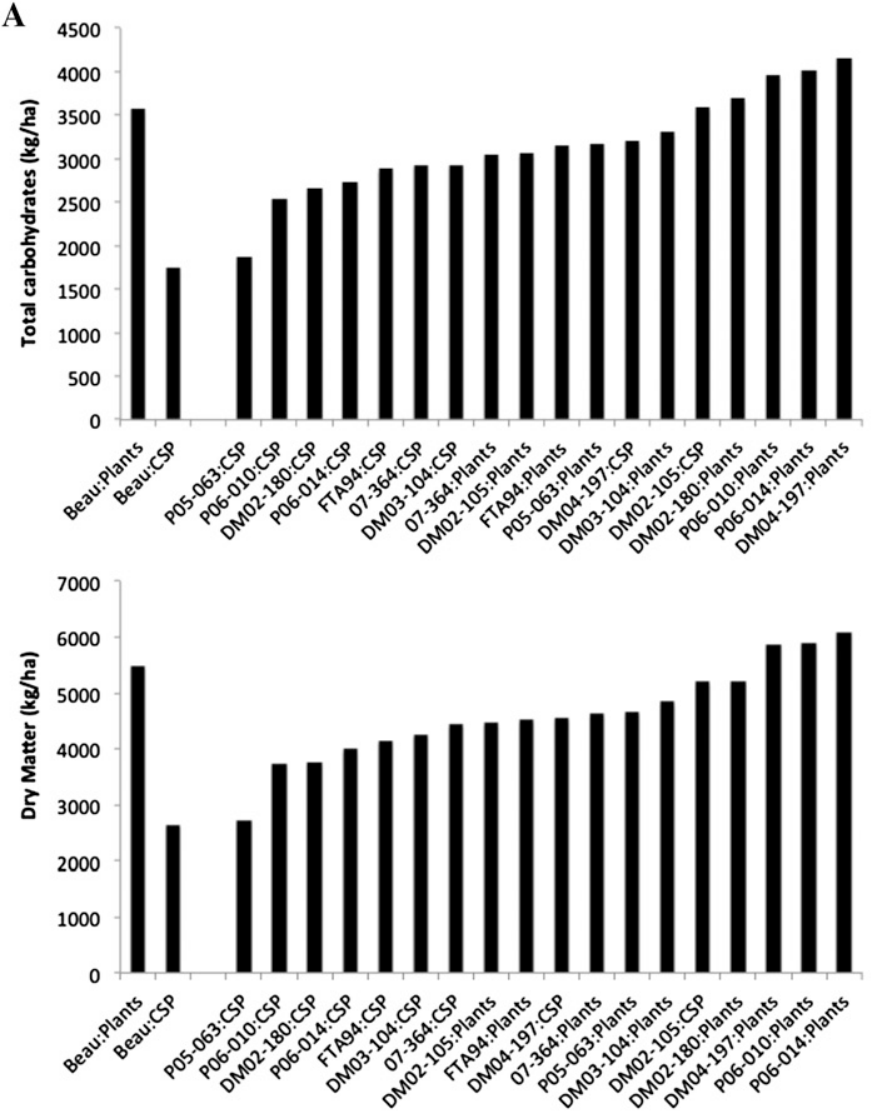

C

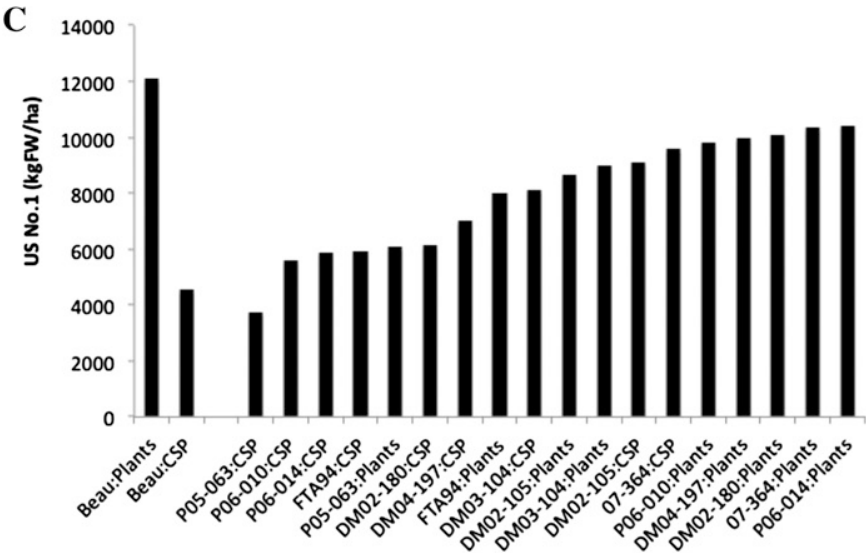

B
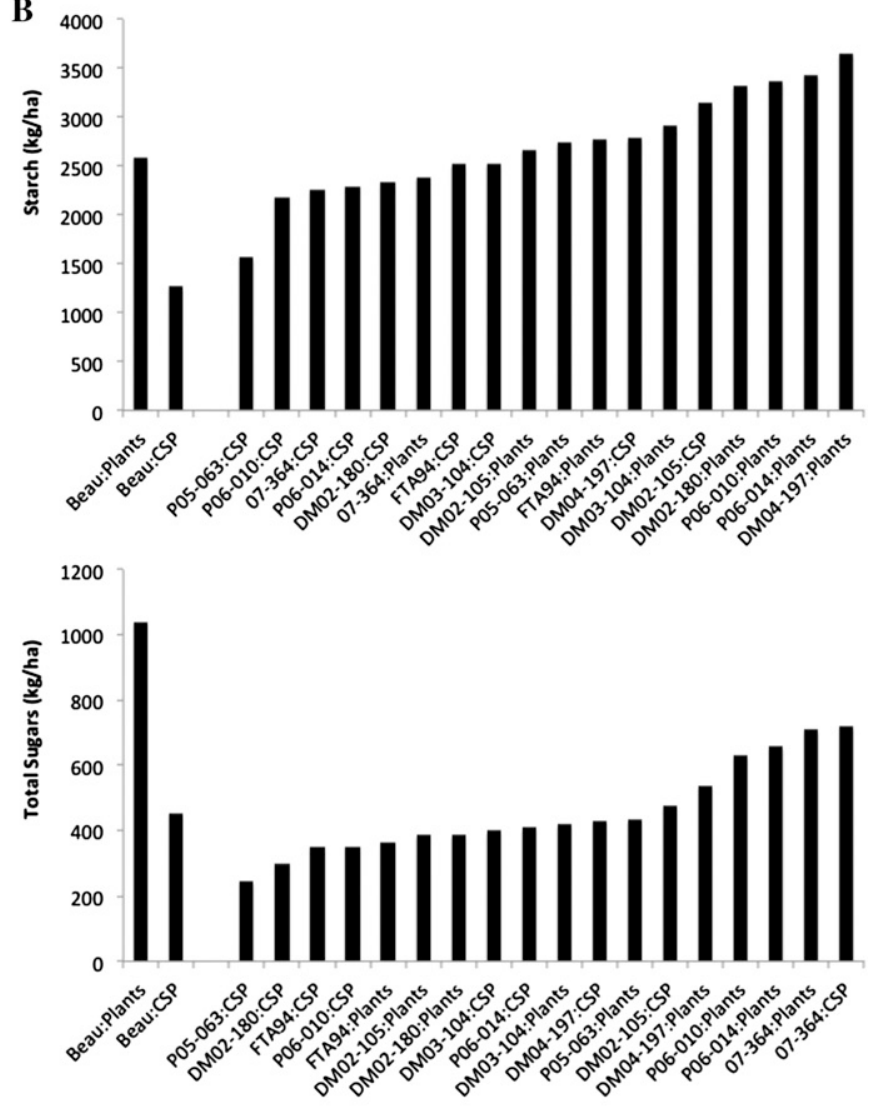

Fig. 2. The yield of the sweetpotato clones tested in this study (best linear unbiased predictors from linear model). Beau = Beauregard; plants = planted as slips; $\mathrm{CSP}=$ planted as root pieces. Error estimates at not shown for individual grouping factors given these are random terms in the model (Bates, 2010).

Table 3. The correlation between different sweetpotato root constituents measured in this study (all pairwise correlations were found to be highly significant).

\begin{tabular}{lcccccc}
\hline & Starch & Fructose & Glucose & Sucrose & Total sugars & Total carbohydrates \\
\hline Dry matter & 0.80 & -0.76 & -0.77 & 0.68 & -0.84 & 0.41 \\
Starch & & -0.78 & -0.77 & 0.64 & -0.85 & 0.76 \\
Fructose & & & 0.99 & 0.48 & 0.89 & -0.31 \\
Glucose & & & & 0.47 & 0.87 & -0.30 \\
Sucrose & & & & & 0.80 & -0.16 \\
Total sugars & & & & & & -0.29 \\
\hline
\end{tabular}

\section{Results}

Over the two seasons, the sites were similar in terms of temperature and season length; however, there was variation in terms of total seasonal rainfall and rainfall distribution (Table 2). For example, the Oxford site received only $250 \mathrm{~mm}$ of seasonal rainfall in 2011, and the Tidewater site was inundated by water in 2011 following Hurricane Irene. The Reidsville site was defoliated by deer grazing in late Sept. 2010 after a protective electric fence failed. These events are within the range of what could be experienced by commercial growers in this region.

Summary of composition and yields, and the composition and yields of high-dry matter clones relative to Beauregard. Individual highdry matter clones achieved higher mean dry matter contents than Beauregard, and the starch and total carbohydrate content of the high-dry matter clones were also mostly higher than Beauregard (Fig. 1). Beauregard displayed the highest total sugar content of all the clones. The clone NC07-364, a low-dry matter clone, also displayed low dry matter and high sugar content. The composition of the roots was unaffected by planting method.

A number of high-dry matter clones, but not all, achieved greater total yields of dry matter, starch, and total carbohydrates than 
Beauregard, whereas Beauregard had the highest mean yield of sugars (Fig. 2). Yields from clones planted as slips were higher than the same clones planted as root pieces, with the exception of NCDM02-105. The highest mean carbohydrate yield was 4150 $\mathrm{kg} \cdot \mathrm{ha}^{-1}$ for clone NCDM04-197 grown from slips, compared with $3580 \mathrm{~kg} \cdot \mathrm{ha}^{-1}$ for Beauregard grown from slips. In contrast, the highest overall carbohydrate yield from root pieces was $3600 \mathrm{~kg} \cdot \mathrm{ha}^{-1}$ for the clone NCDM02-105. The total carbohydrate yield of NC07-364 was similar for both slips and root pieces.

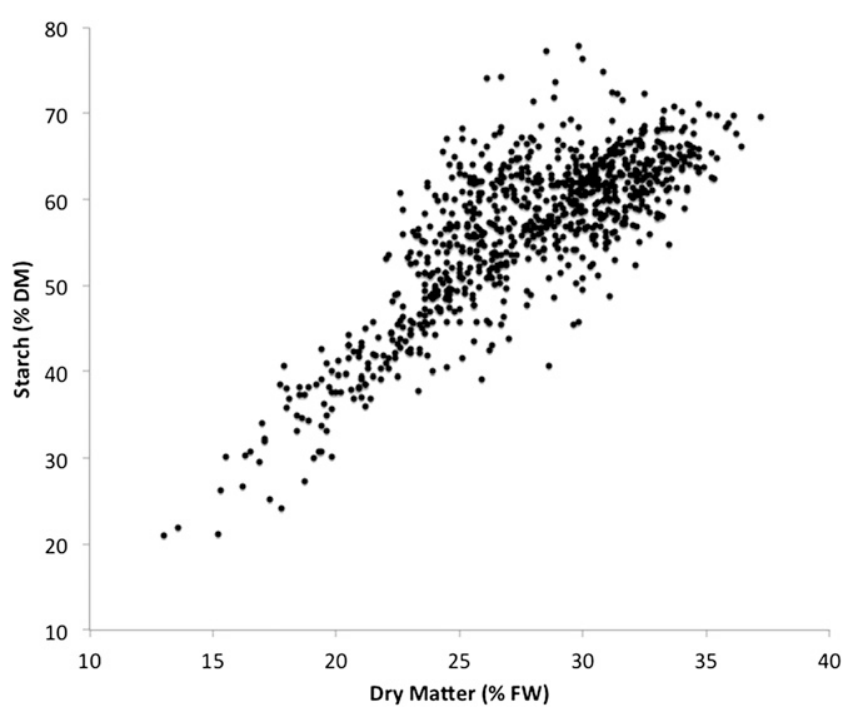

Fig. 3. The relationship between dry matter and starch content for all samples measured in this study.

Table 4 . The correlation between root dry matter and starch content relative to total dry matter content for individual sweetpotato clones.

\begin{tabular}{lcc}
\hline Clone & Dry matter content (\%) & Dry matter starch correlation \\
\hline NC07-364 & 20.9 & 0.90 \\
Beauregard & 22.1 & 0.83 \\
NCP06-010 & 28.1 & 0.91 \\
NCDM02-105 & 28.3 & 0.72 \\
NCDM03-104 & 28.4 & 0.60 \\
NCDM04-197 & 28.4 & 0.53 \\
NCFTA94 & 29.0 & 0.59 \\
NCDM02-180 & 29.9 & 0.47 \\
NCP06-014 & 30.3 & 0.64 \\
NCP05-063 & 30.8 & 0.75 \\
\hline
\end{tabular}

Correlations between constituents. A strong positive relationship was found between starch and dry matter content (Tables 2 and 3); however, the relationship was observed to be poorer at dry matter contents above $\approx 25 \%$ (Fig. 3; Table 4). A strong correlation was found between starch and dry matter at dry matter contents of less than $25 \%(r=0.87)$, but above $25 \%$ dry matter the relationship was weaker $(r=0.47)$. Site and year did not affect the relationship between starch and dry matter. The strength of the relationship was found to vary depending on clone (Table 4). Individual clones with a low dry matter had a strong correlation between dry matter and starch content. Clones with high dry matter were less consistent, some displayed a strong correlation and some a poor correlation. Fructose and glucose showed a very close positive correlation. Sugar content and starch displayed a strong negative correlation.

The significance of main effects and their interaction on root composition and total yield. The main effects (site, year, and clone) and their second- and third-order interactions were found to significantly influence storage root composition and total yield of all the measured constituents (Tables 5 and 6). The first-order main effects, and the secondorder clone by environment interaction, generally accounted for most of the variance in the model for storage root composition. The planting method (either slips or root pieces) did not have a significant effect on storage root composition. The yield of carbohydrates was strongly influenced by planting method. When slips and storage root pieces were considered separately the influence of main effects and their interactions were complicated (Table 7). Site and clone were found to strongly influence the yield of crops grown from slips, whereas year and site by year tended to have greater influence on crops grown from root pieces. Yields at individual sites could not be readily attributed to factors such as temperature, precipitation, or measured soil nutrient status.

Table 5. Variance components and significance tests of the main effects and their interactions for the percentage composition of sweetpotato storage roots.

\begin{tabular}{|c|c|c|c|c|c|c|c|c|}
\hline & Degrees of freedom & Dry matter & Starch & Glucose & Fructose & Sucrose & Total sugars & Total carbohydrates \\
\hline$\overline{\text { SITE }}$ & 40 & $69.8^{* *}$ & $70.5^{* *}$ & $63.7^{* *}$ & $31.5^{* *}$ & $7.9^{* *}$ & $19.8^{* *}$ & $143.3^{* *}$ \\
\hline CLONE & 411 & $526.2^{* *}$ & $423.3 * *$ & $594.8^{* *}$ & $478.8^{* *}$ & $207.4^{* *}$ & $733.8^{* *}$ & $96.6^{* *}$ \\
\hline PLANTMETHOD & 411 & 1 & 2.3 & 3.7 & 2 & $14.2 * *$ & 0.3 & $4.3^{*}$ \\
\hline SITE:YEAR & 40 & $50.9 * *$ & $47.2 * *$ & $35.2 * *$ & $32.9 * *$ & $25.3 * *$ & $30.6^{* *}$ & $34.5^{* *}$ \\
\hline SITE:CLONE & 411 & $5.2 * *$ & $6.8^{* *}$ & $29.4 * *$ & $22 * *$ & $7.7^{* *}$ & $9.8^{* *}$ & $6.4^{* *}$ \\
\hline YEAR:CLONE & 411 & $81.7 * *$ & $12.2 * *$ & $39.4 * *$ & $43.9^{* *}$ & $26.7 * *$ & $30.1 * *$ & $3.1 * *$ \\
\hline CLONE:PLANTMETHOD & 411 & $3.1 * *$ & 1 & 1.3 & 1.6 & 1.5 & 2 & 0.3 \\
\hline SITE:YEAR:CLONE & 411 & $3.7^{* *}$ & $2.4^{* *}$ & $15.6^{* *}$ & $11.6^{* *}$ & $3.3^{* *}$ & $3.3^{* *}$ & $2 * *$ \\
\hline SITE:YEAR:PLANTMETHOD & 411 & 1.5 & 2.1 & 1.3 & 1 & 0.8 & 0.7 & 2.2 \\
\hline SITE:CLONE:PLANTMETHOD & 411 & $1.7^{*}$ & 0.7 & 0.9 & 0.9 & 1.4 & 1.1 & 1.1 \\
\hline YEAR:CLONE:PLANTMETHOD & 411 & 0.4 & 0.4 & 1.9 & $2.7^{*}$ & 0.6 & 2.2 & 0.8 \\
\hline
\end{tabular}

PLANTMETHOD = Indicates planting method, either slips or root pieces.

F-statistic. ${ }^{*}$ Indicates significance at $P=0.05,{ }^{*}$ indicates significance at $P=0.01$. 
Table 6. Variance components and significance tests of the main effects for the carbohydrate yield of sweetpotato storage roots.

\begin{tabular}{|c|c|c|c|c|c|c|c|c|}
\hline & Degrees of freedom & Dry matter & Starch & Glucose & Fructose & Sucrose & Total sugars & Total carbohydrates \\
\hline$\overline{\text { SITE }}$ & 40 & $60.4 * *$ & $74.3 * *$ & $72.1 * *$ & $53.3 * *$ & $34.3 * *$ & $37.4 * *$ & $71.8^{* *}$ \\
\hline YEAR & 40 & $35.4 * *$ & $47.1 * *$ & $112^{* *}$ & $83.5 * *$ & $7.9 * *$ & $6.1^{*}$ & $28.8 * *$ \\
\hline CLONE & 411 & $14.7 * *$ & $21.5 * *$ & $159.1 * *$ & $124.2 * *$ & $53.7 * *$ & $91.5 * *$ & $15.1 * *$ \\
\hline PLANTMETHOD & 411 & $133 * *$ & $111.4 * *$ & $58.6^{* *}$ & $56.2 * *$ & $110.2 * *$ & $149.7 * *$ & $121.9 * *$ \\
\hline SITE:YEAR & 40 & $44.1 * *$ & $46.6 * *$ & $53.7 * *$ & $52.3 * *$ & $53.3 * *$ & $54.7 * *$ & $50.1 * *$ \\
\hline SITE:CLONE & 411 & $5.9 * *$ & $6.1 * *$ & $29.1 * *$ & $27.8 * *$ & $7.6^{* *}$ & $13.9 * *$ & $5.7 * *$ \\
\hline YEAR:CLONE & 411 & $6.7 * *$ & $7.1 * *$ & $5.9 * *$ & $6.8 * *$ & $5.3 * *$ & $7.7 * *$ & $7.6 * *$ \\
\hline SITE:PLANTMETHOD & 411 & $13.4 * *$ & $15.2 * *$ & $15.3 * *$ & $10.7 * *$ & $7.9 * *$ & $10.1 * *$ & $14.4^{* *}$ \\
\hline YEAR:PLANTMETHOD & 411 & $7.3 * *$ & $6.8 * *$ & 0.1 & 0.2 & $11 * *$ & $9.6 * *$ & $6.8 * *$ \\
\hline CLONE:PLANTMETHOD & 411 & $14.5 * *$ & $11 * *$ & $42.9 * *$ & $36.8 * *$ & $23.2 * *$ & $41 * *$ & $13.4 * *$ \\
\hline SITE:YEAR:CLONE & 411 & $2.5 * *$ & $3 * *$ & $16.2 * *$ & $14.8 * *$ & $4.3 * *$ & $4.5^{* *}$ & $2.6^{* *}$ \\
\hline SITE:YEAR:PLANTMETHOD & 411 & $22.4 * *$ & $20.2 * *$ & $13.6 * *$ & $13.2 * *$ & $20.4 * *$ & $21.3 * *$ & $22.2 * *$ \\
\hline SITE:CLONE:PLANTMETHOD & 411 & $2.1 * *$ & $2.4^{* *}$ & $8.8 * *$ & $7.9 * *$ & $2.7 * *$ & $3.5^{* *}$ & $2.3^{* *}$ \\
\hline YEAR:CLONE:PLANTMETHOD & 411 & 0.5 & 0.4 & $2.9 *$ & $5.1 * *$ & 2.2 & $2.7^{*}$ & 0.4 \\
\hline SITE:YEAR:CLONE:PLANTMETHOD & 411 & $1.6^{*}$ & 1.5 & $7.6^{* *}$ & $7.2^{* *}$ & $2.6^{* *}$ & $3.4^{* *}$ & $1.6^{*}$ \\
\hline
\end{tabular}

PLANTMETHOD $=$ indicates planting method, either slips or root pieces.

F-statistic. *Indicates significance at $P=0.05, * *$ indicates significance at $P=0.01$.

Table 7. Variance components and significance tests of the main effects for the total yields of carbohydrates measured in this study, considering storage root pieces and slips separately.

\begin{tabular}{|c|c|c|c|c|c|c|c|c|c|}
\hline & Degrees of freedom & Standcount & $\mathrm{DM}$ & Starch & Glucose & Fructose & Sucrose & Sugars & Carbs \\
\hline \multicolumn{10}{|l|}{ Root pieces } \\
\hline SITE & 40 & $42.2 * *$ & $35 * *$ & $39.3 * *$ & $29.1 * *$ & $17.2 * *$ & $29.4 * *$ & $22.9 * *$ & $39.3 * *$ \\
\hline YEAR & 40 & $6.7^{*}$ & $21.8 * *$ & $28.1 * *$ & $4.7 *$ & $6.6^{*}$ & 2.1 & $0.1^{*}$ & $19.7 * *$ \\
\hline CLONE & 197 & $22.9 * *$ & $19.9 * *$ & $23.6 * *$ & $26.7 * *$ & $22.5 * *$ & $12 * *$ & $14.4 * *$ & $21.2 * *$ \\
\hline SITE:YEAR & 40 & $5.5 * *$ & $13.2 * *$ & $13.8 * *$ & $22.8 * *$ & $16.9 * *$ & $17.6 * *$ & $19.5 * *$ & $14.7 * *$ \\
\hline SITE:CLONE & 197 & $6.8 * *$ & $5.8 * *$ & $6.5 * *$ & $10 * *$ & $10 * *$ & $5.3 * *$ & $5.3 * *$ & $6.1^{* *}$ \\
\hline YEAR:CLONE & 197 & $20.9 * *$ & $6 * *$ & $6.4 * *$ & $4.8 * *$ & $4.9 * *$ & 0.6 & $3.3 * *$ & $6.5 * *$ \\
\hline SITE:YEAR:CLONE & 197 & $3.1 * *$ & $2.3^{* *}$ & $2.6 * *$ & $2.5 * *$ & $2.1 * *$ & $3.3^{* *}$ & $1.7^{*}$ & $2.3 * *$ \\
\hline \multicolumn{10}{|l|}{ Slips } \\
\hline SITE & 40 & $134.1 * *$ & $82.9 * *$ & $116.1^{* *}$ & $52.9 * *$ & $39.7 * *$ & $20.8 * *$ & $32 * *$ & $90.7 * *$ \\
\hline YEAR & 40 & $6.3^{*}$ & $39.9 * *$ & $45.9 * *$ & $128 * *$ & $83.8 * *$ & $1 *$ & $1.8^{*}$ & $30.3 * *$ \\
\hline CLONE & 292 & $4.9 * *$ & $10.7 * *$ & $12.8 * *$ & $155.2 * *$ & $111.3 * *$ & $55 * *$ & $95.3 * *$ & $9.4 * *$ \\
\hline SITE:YEAR & 40 & $36.6 * *$ & $69.8 * *$ & $67.1 * *$ & $41.3 * *$ & $39.5 * *$ & $55^{* *}$ & $55.5 * *$ & $73.8^{* *}$ \\
\hline SITE:CLONE & 292 & $5.9 * *$ & $4.7 * *$ & $4.5^{* *}$ & $22 * *$ & $20.5 * *$ & $6.7 * *$ & $12.5 * *$ & $4.4^{* *}$ \\
\hline YEAR:CLONE & 292 & $3.9 * *$ & 2.6 & 2.7 & $7.5^{* *}$ & $5.2 * *$ & $5.7 * *$ & $5.3 * *$ & 3 \\
\hline SITE:YEAR:CLONE & 292 & $2.1 * *$ & 1.9 & 1.8 & $19.7 * *$ & $17.3 * *$ & $3.6 * *$ & $5.3 * *$ & 1.9 \\
\hline
\end{tabular}

F-statistic. *Indicates significance at $P=0.05, * *$ indicates significance at $P=0.01$.

Nonparametric stability analysis. Significant instability of clone ranking across sites and years was detected for dry matter content and the total yield of carbohydrates, and significant instability of clone variance across sites and years was detected for dry matter content, total sugar content, and total sugar yield (Table 8 ). Ranking and variance stabilities for clones grown from root pieces were not significantly different from the same clones grown from slips (data not shown).

\section{Discussion}

The carbohydrate yield of sweetpotato. There is interest in the potential of sweetpotato as a crop for the production of carbohydrates for industrial end uses. Ziska et al. (2009) reported the carbohydrate yield from the sweetpotato cultivar Beauregard could be double that of corn in the eastern United States. Our research compared the carbohydrate yield of the sweetpotato cultivar Beauregard with clones specifically selected for higher carbohydrate yields. We found three

Table 8. Nonparametric yield stability estimates of sweetpotato grown from root pieces averaged across three seasons.

\begin{tabular}{lcc}
\hline Rank & $\begin{array}{c}\text { Approximate test of } \\
\text { significance for rank }\end{array}$ & $\begin{array}{c}\text { Approximate test of } \\
\text { significance for variance }\end{array}$ \\
\hline Dry matter (\% fresh weight) & $23.9^{* *}$ & $24.0^{* *}$ \\
Starch (\% dry weight) & 13.9 & 14.4 \\
Total Sugars (\% dry weight) & 12.3 & $30.2^{* *}$ \\
Total carbohydrates (\% dry weight) & $22.9 * *$ & 20.9 \\
Dry matter $\left(\mathrm{kg} \cdot \mathrm{ha}^{-1}\right)$ & 10.0 & 10.2 \\
Starch $\left(\mathrm{kg} \cdot \mathrm{ha}^{-1}\right)$ & 13.9 & 14.4 \\
Total sugars $\left(\mathrm{kg}^{-1} \mathrm{ha}^{-1}\right)$ & 12.3 & $30.2^{* *}$ \\
Total carbohydrates $\left(\mathrm{kg} \cdot \mathrm{ha}^{-1}\right)$ & 8.6 & 9.3 \\
\hline
\end{tabular}

$\chi^{2}=21.0$. Values greater than $\chi^{2}$ indicated instability for either mean rank or variance.

**Indicates significance at $P=0.01$.

clones that had a greater carbohydrate yield than Beauregard. The average total carbohydrate yield for Beauregard obtained in our study was $3580 \mathrm{~kg} \cdot \mathrm{ha}^{-1}$, while a high-dry matter clone achieved $4150 \mathrm{~kg} \cdot \mathrm{ha}^{-1}$. The average yield of corn in North Carolina between 2003 and 2013 was $7400 \mathrm{~kg} \cdot \mathrm{ha}^{-1}$ (NASS, 2015); the total carbohydrate yield from this would be on average $5400 \mathrm{~kg} \cdot \mathrm{ha}^{-1}$, assuming a carbohydrate content of $\approx 70 \%$ (Lunven, 1992; Smith et al., 2004). The carbohydrate yields from the best sweetpotato clones in our study were therefore lower than that for corn.

The carbohydrate yield of Beauregard in our study was lower than that reported by Ziska et al. (2009). Ziska et al. (2009) found the mean total carbohydrate yield for the cultivar Beauregard to be $11,000 \mathrm{~kg} \cdot \mathrm{ha}^{-1}$. The highest yield achieved by Beauregard in our study was around $9000 \mathrm{~kg} \cdot \mathrm{ha}^{-1}$, but across sites and years it was $3580 \mathrm{~kg} \cdot \mathrm{ha}^{-1}$. The study by Ziska et al. (2009) was 
conducted at two sites in a single season and used supplemental irrigation. Our study was conducted at five sites over two seasons and did not use supplemental irrigation. We believe the carbohydrate yields obtained in our work are more representative of what can be expected over regional and multiyear scales under commercial production conditions.

The effect of planting via slips vs. root pieces. Sweetpotato is relatively costly to produce, and to be economically viable as a carbohydrate crop steps need to be taken to reduce production costs. We compared conventional planting using slips to root pieces, which can be planted mechanically and potentially more cheaply (George et al., 2011). We found that planting method did not significantly influence root composition, however, clones planted from root pieces tended to have lower yields overall. This is a well-established problem in sweetpotato and shows that root pieces are generally not a viable alternative to slips for current clones. The exception was for the clone NCDM02-105, which produced higher carbohydrate yields from root pieces than slips, and NC07-364, which had similar carbohydrate yields for both slips and root pieces. This demonstrates that it is possible to select for adaptation to root piece planting. Further work is needed to develop highyielding sweetpotato clones that are also adapted to planting as root pieces.

$G \times E$ effects. The chemical composition and yield of sweetpotato were both significantly impacted by genotype $\times$ environment effects, and in some cases, these effects resulted in significant changes in variety rankings. We could not attribute the yield variation between sites and years was to environmental factors. This is in agreement with other studies of sweetpotato (Collins et al., 1987; George et al., 2011, 2014; Grüneberg et al., 2005; Kanua and Floyd, 1988; Manrique and Hermann, 2002; Ngeve, 1993). Clones planted as root pieces did not display greater instability than the same clones planted as slips, although factors influencing composition and yield did vary between clones and slips. Site and clone were important for slips, and year and site by year tended to have greater influence for root pieces. The reasons for this are unclear.

Significant $G \times E$ effects will make it difficult to predict the performance of new sweetpotato clones between years and in new environments. To address this, the development of new sweetpotato clones for industrial carbohydrate production will need to include the testing of material in appropriately designed multienvironmental trials.

Dry matter vs. starch content. It is generally accept that starch and dry matter content are closely correlated in sweetpotato (Brabet et al., 1998; Mok et al., 1997), however, our work found that dry matter is not necessarily a reliable substitute for starch content. The overall lack of correlation in our data was due to specific, moderate to high dry matter, clones. This suggests it may be necessary to directly measure starch content when selecting for sweetpotato clones for bulk carbohydrate production. This is problematic because it is cheaper and simpler to measure root dry matter than to directly measure starch. The correlations between starch and dry matter in high-dry matter sweetpotato clones should therefore be investigated further.

\section{Conclusions}

Our study found that sweetpotato clones specifically selected for high dry matter can produce greater yields of carbohydrates than the existing commercial sweetpotato cultivar Beauregard, which was developed for human consumption. Total carbohydrate yields of over $4000 \mathrm{~kg} \cdot \mathrm{ha}^{-1}$ could be expected. The high-dry matter clones tested in our study achieved dry matter contents $10 \%$ to $15 \%$ higher than Beauregard, but lacked the yield potential of Beauregard, and therefore carbohydrate yield per unit land area were not as high as hoped. Planting using root pieces reduced total carbohydrate yields relative to slips. Further work will be needed to develop sweetpotato clones with both high carbohydrate content and high yield potential, and that are also adapted to planting from root pieces. We recommend that this work be conducted in appropriately designed multienvironment trials so as to capture $\mathrm{G} \times \mathrm{E}$ effects. Finally, we also suggest that economic analyses of the potential cost savings from root piece planting in sweetpotato production be conducted.

\section{Literature Cited}

Bates, D., M. Maechler, B. Bolker, and S. Walker. 2013. lme4: Linear mixed-effects models using Eigen and S4. R package version 1.0-5. $<\mathrm{http}: / /$ CRAN.R-project.org/package $=1 \mathrm{me} 4>$.

Bates, D.M. 2010. lme4: Mixed-effects modeling with R. p. 145. Springer.

Beutler, H.-O. 1988. D-Fructose, p. 321-327. In: H.U. Bergmeye (ed.). Methods of enzymatic analysis. VCH Publishers (UK) Ltd., Cambridge, UK.

Brabet, C., D. Reynoso, D. Dufour, C. Mestres, J. Arredondo, and G. Scott. 1998. Starch content and properties of 106 sweetpotato clones from the world germplasm collection held at CIP, Peru, p. 279-286, Impact on a changing world. Program Report 1997-98. International Potato Center, Lima, Peru.

Carl, P. and G. Peterson. 2013. PerformanceAnalytics: Econometric tools for performance and risk analysis. R package version 1.1.0. $<$ http://CRAN.R-project.org/ package $=$ PerformanceAnalytics $>$.

Collins, W.W., L.G. Wilson, S. Arrendell, and L.F. Dickey. 1987. Genotype x environment interactions in sweet-potato yield and quality factors. J. Amer. Soc. Hort. Sci. 112:579-583.

Estes, E., J. Schultheis, and H. Sampson. 2002. Sweet potato enterprise budget worksheet. NC State University, Raleigh, NC.

FAOSTAT. 2014. Food and Agriculture Organization of the United Nations. July 2015. <http:// faostat3.fao.org/home/E>.

George, N., M. Shankle, J. Main, K.V. Pecota, C. Arellano, and G.C. Yencho. 2014. Sweetpotato grown from root pieces displays a significant genotype $\mathrm{x}$ environment interaction and yield instability. HortScience 49:984-990.

George, N.A., K.V. Pecota, B.D. Bowen, J.R. Schultheis, and G.C. Yencho. 2011. Root piece planting in sweetpotato - a synthesis of previous research and directions for the future. HortTechnology 21:703-711.

Grüneberg, W.J., K. Manrique, D. Zhang, and M. Hermann. 2005. Genotype x environment interactions for a diverse set of sweetpotato clones evaluated across a varying ecogeographic conditions in Peru. Crop Sci. 45:2160-2171.

Hinson, R.A. and J.E. Boudreaux. 2007. Louisiana vegetable crops. Louisiana State University Department of Agricural Economics \& Agribusiness. A.E.A. Information Series No. 246. p. 100.

Huehn, M. 1990. Nonparametric measures of phenotypic stability. Part 1: Theory. Euphytica 47:189-194.

Kanua, M.B. and C.N. Floyd. 1988. Sweet-potato genotype $\mathrm{x}$ environment interactions in the highlands of Papua-New-Guinea. Trop. Agr. 65:9-15.

Kunst, A., B. Draeger, and J. Zeiegenhorn. 1988 D-Glucose, p. 163-172. In: H.U. Bergmeye (ed.). Methods of enzymatic analysis. VCH Publishers (UK) Ltd., Cambridge, UK.

Lunven, P. 1992. Maize in human nutrition. Food and Agriculture Organization of the United Nations, Rome. <http://www.fao.org/docrep/ t0395e/t0395e00.HTM>

Manrique, K. and M. Hermann. 2002. Effect of GxE interaction on root yield and betacarotene content of selected sweetpotato (Ipomoea batatas (L) Lam.) varieties and breeding clones, p. 281-286. Scientist and farmer: Partners in research for the 21st century. Program Report, 1999-2000. Program Report 1999-2000. International Potato Center, Lima, Peru.

Martin, D.A., R.D. Myers, and C.A. McClurg. 2000. Growing sweet potatoes. Maryland Cooperative Extension, University of Maryland. Fact Sheet 464

Mendiburu, F.d. 2013. agricolae: Statistical procedures for agricultural research. $\mathrm{R}$ package version 1.1-4. <http://CRAN.R-project.org/ package $=$ agricolae $>$.

Mok, I.G., L. Tjintokohadi, L. Nigsih, and T.D. Hoang. 1997. Sweetpotato breeding strategy and germplasm testing in Southeast Asia. International Potato Center Program Report 1995-96. International Potato Center, Lima, Peru. p. $104-109$.

MSU. 2007. Traditional and organic vegetables 2008 planning budgets. Mississippi State University Department of Agricultural Economics. Budget Report 2007-08.

NASS. 2015. National Agricultural Statistics Service (NASS), United States Department of Agriculture. July 2015. <http://www.nass.usda.gov/>.

Ngeve, J.M. 1993. Regression analysis of genotype $\mathrm{x}$ environment interaction in sweet-potato. Euphytica 71:231-238.

NRCS. 2013. Web soil survey. United States Department of Agriculture, Natural Resources Conservation Service. $<$ http://websoilsurvey.nrcs.usda.gov/ app/>.

Outlaw, W.H. and C.T. Mitchell. 1988. Sucrose, p. 96-103. In: H.U. Bergmeye (ed.). Methods of enzymatic analysis. VCH Publishers (UK) Ltd., Cambridge, U.K.

Pinheiro, J.C. and D.M. Bates. 2000. Mixed-effects models in S and S-PLUS. Springer, New York, NY. p. 528.

R Core Team. 2014. R: A language and environment for statistical computing. R Foundation for Statistical Computing, Vienna, Austria.

Rolston, L.H., C.A. Clark, J.M. Cannon, W.M. Randle, E.G. Riley, P.W. Wilson, and M.L. Robbins. 1987. 'Beauregard' sweet potato. HortScience 22:1338-1339. 
Smith, A.B., B.R. Cullis, and R. Thompson. 2005. The analysis of crop cultivar breeding and evaluation trials: An overview of current mixed model approaches. J. Agr. Sci. 143:449-462.

Smith, C.W., J. Betrán, and E.C.A. Runge. 2004 Corn: Origin, history, technology, and production, p. 949. Wiley, Hoboken, NJ.

Truberg, B. and M. Huhn. 2000. Contributions to the analysis of genotype $x$ environment interactions: Comparison of different parametric and non-parametric Tests for interactions with emphasis on crossover interactions. J. Agron. Crop Sci. 185:267-274.

United States Sweet Potato Council. 2011. The United States Sweet Potato Council Inc. Columbia, SC. $<$ http://www.sweetpotatousa.org $>$.

USNO. 2012. Sun or moon rise/set table for one year. U.S. Navy Astronomical Application Department. $<$ http://aa.usno.navy.mil/data/docs/ RS_OneYear.php>.

Villordon, A., C. Clark, D. Ferrin, and D.R LaBonte. 2009. Using growing degree days, agrometeorological variables, linear regression, and data mining methods to help improve prediction of sweetpotato harvest date in Louisiana. HortTechnology 19:133144

Ziska, L.H., G.B. Runion, M. Tomecek, S.A. Prior, H.A. Torbet, and R. Sicher. 2009. An evaluation of cassava, sweet potato and field corn as potential carbohydrate sources for bioethanol production in Alabama and Maryland. Biomass Bioenergy 33:1503-1508. 